\title{
New records to the Bryoflora of the Sudan Republic.
}

\author{
Hanaa M. Shabbara \\ Botany Department, Faculty of Science \\ Ain Shams University, Cairo- Egypt. \\ Nady A. Ghanem \\ Botany and Microbiology Department, \\ Faculty of Science, Al-Azhar University. \\ Cairo- Egypt.
}

\author{
And \\ Wagieh El- Saadawi \\ Botany Department, Faculty of Science \\ Ain Shams University, Cairo- Egypt. \\ E- mail: elsaadawy@link.com.eg
}

Shabbara H.M., Ghanem N.A.\& El-Saadawi W., 1999. New records to the Bryoflora of the Sudan Republic. Taeckholmia 19(1): 17-25.

\footnotetext{
Five mosses are reported as new records to the Khartoum Province. This brings the number of fully identified mosses known from this Province to 11 entities. The main floral elements in the studied localities are species of Philonotis.

The total number of fully identified mosses, for the Sudan, is increased from 23 to 31 entities. Four of the eight new to Sudan records resulted from this work while the other four were erroneously regarded earlier as elements of the Egyptian flora.

Key words: Bryoflora, Mosses, Sudan.
}

\section{Introduction:}

The Sudan is a vast African country having an area of more than two million square kilometers. This area includes a number of principal vegetation divisions (Fig.1) among which are: Desert; Semi-desert and Low Rainfall Woodland Savanna (Harrison \& Jackson, 1958). Within these, are areas of Riverain and Montane vegetation (Bebawi \& Neugebohrn, 1991)

So far quite a few works have been published on the bryoflora of the Sudan. Pettet, (1966), dealt with mosses from Khartoum Province which extends from Lat. $15^{\circ} 10^{\prime}$ N. to Lat. $16^{\circ} 30^{\prime}$ N., with the capital city Khartoum lying at the junction between the White Nile and the Blue Nile (Fig.1). He recorded eight mosses; Barbula unguiculata Hedw., Bryum klinggraeffii Schimp., Bryum sp., Funaria hygrometrica Hedw., Funaria nutans Mitt., Micropoma niloticum (Delile) Lindb., Philonotis sp. and Tortula bogosica (Müll. Hal.) Zander from the irrigated gardens and riverain areas in this province. Only one of these eight mosses viz. Tortula bogosica (Müll. Hal.) Zander was later recorded by Townsend, (1984) from Marra montane area. 
Wickens (1976), worked on Gebel Marra; an isolated volcanic massif in the central west near the border with Chad (Fig.1). From this montane area Wickens (op. cit.) recorded eight mosses. Townsend (1984), added another 14 from the same area.

In addition to these 22 taxa of Gebel Marra, four mosses were collected, in Jan. 1962, by M. Kassas, from the Sudanese side of Elba Montane area (Fig.1), which consists of nine extensive granite coastal mountains occupying the southeastern corner of Egypt and the northeastern corner of the Sudan (Fig.1). These four Sudanese mosses viz. Bryum cellulare Hook., Entosthodon durieui Mont.(= Funaria pallesens (Jur.) Lindb.), Funaria muhlenbergii Turner\& Hyophila laxitexta J. Froehl., were regarded by Imam \& Ghabbour (1972) as elements in the Egyptian Flora. However, being in reality from the Sudan, they are to be considered as new records to this country; which means that, at least, 26 montane taxa are known from the Sudan.

The present work deals with mosses from Khartoum Province, however, from localities different from those reported by Pettet (1966).

Fig. 1. Map of the Sudan showing the principal vegetation divisions. Mainly after Bebawi and Neugebohrn 1991. 


\section{Localities and Materials}

Forty moss samples were collected by the second author between Dec. 1991 and Sept. 1992, from four localities of the Khartoum Province. Moss populations of these samples covered small areas ranging from about $30 \mathrm{~cm}^{2}$ to about $1000 \mathrm{~cm}^{2}$. The total cover area of the four localities, arranged in descending order, were:

- El-Mazad (11 samples), $\pm 3900 \mathrm{~cm}^{2}$.

- El-Safia (10 samples), $\pm 2300 \mathrm{~cm}^{2}$.

- Sa'ad-Keshra (11 samples), $\pm 1500 \mathrm{~cm}^{2}$.

- Shambat (8 samples), $\pm 500 \mathrm{~cm}^{2}$.

The collected mosses were found growing in moist places including:

$1-$

Outer surfaces, covered with thin layers of mud of large-sized drinking-water pottery pots (locally known as "Zeers"), placed in shade usually of large trees (24 samples).

2- $\quad$ Moist shady soil, inhabited by grasses, near the "Zeers" (14 samples).

3- $\quad$ Moist wood fragment (one sample).

4- $\quad$ Moist red-brick (one sample).

Most of the samples were collected during winter months (Dec.- March) which are the favourable for the growth of mosses in the study area.

\section{Observations and Descriptions}

Thirty-five out of the 40 collected moss samples included one species each. The other five samples had two species each. Six taxa were identified to the specific level and one taxon to the generic level (Table 1).

Table (1): Records of the identified taxa in different localities and micro-habitats. $\mathrm{B}=$ brick, $\mathrm{M}=$ El-Mazad, $\mathrm{S}=$ Moist soil, $\mathrm{Sa}=\mathrm{El}-\mathrm{Safia}, \mathrm{Sh}=$ Shambat, $\mathrm{S}-\mathrm{K}=\mathrm{Sa}$ 'ad-Keshra, $\mathrm{T}=$ Total, $\mathrm{W}=$ Wood, $\mathrm{Z}=$ 'Zeer', * = New record to the Sudan including Khartoum Province, $\bullet=$ new record to Khartoum Province.

\begin{tabular}{|c|c|c|c|c|c|c|c|c|c|c|}
\hline \multirow{3}{*}{ Taxon } & \multirow{3}{*}{$\begin{array}{l}\text { No. of } \\
\text { Loca- } \\
\text { lities }\end{array}$} & \multicolumn{9}{|c|}{ No. of samples collected from each: } \\
\hline & & \multicolumn{4}{|c|}{ Locality } & \multicolumn{5}{|c|}{ Micro-habitat } \\
\hline & & $\mathrm{M}$ & $\mathrm{Sa}$ & S-k & $\mathrm{Sh}$ & $\mathrm{Z}$ & $\mathrm{S}$ & $\mathrm{W}$ & $\mathrm{B}$ & $\mathrm{T}$ \\
\hline $\begin{array}{l}\text { *Philonotis hastata (Duby) Wijk. } \\
\text { \& Margad. }\end{array}$ & 4 & 11 & 1 & 5 & 6 & 16 & 6 & 1 & - & 23 \\
\hline $\begin{aligned} \text { *P. fontana } & \text { (Hedw.) Brid. var.? } \\
\text { caespitosa } & \text { (Jur.) Limpr }\end{aligned}$ & 2 & 1 & 7 & - & - & 2 & 6 & - & - & 8 \\
\hline *P. dregeana (Müll. Hal.) A. Jaeger & 3 & 1 & 1 & 4 & - & 5 & 1 & - & - & 6 \\
\hline - P.marchica (Hedw.) Brid. & 1 & - & 2 & - & - & - & 2 & - & - & 2 \\
\hline $\begin{array}{l}\text { *Gymnostomum aeruginosum Sm. } \\
\text { var. cochlearifolium Karczmarz }\end{array}$ & 2 & - & 2 & 2 & - & 2 & 2 & - & - & 4 \\
\hline Funaria hygrometrica Hedw. & 1 & - & - & - & 1 & - & - & - & 1 & 1 \\
\hline Bryum sp. & 1 & - & - & - & 1 & 1 & - & - & - & 1 \\
\hline
\end{tabular}

The above table shows that four of the recorded taxa are new records to the flora of the Sudan and five to Khartoum Province. It will be noticd that Philonotis species dominate the moss flora of the four studied localities (being represented by 36 out of the 
40 collected samples). Philonotis hastata is the most widespread species being recorded in four localities with 23 gatherings. Philonotis fontana var.? caespitosa, P. dregeana and Gymnostomum aeruginosum var. cochlearifolium are less common while Philonotis marchica, Funaria hygrometrica and Bryum sp. are quite rare being collected once or twice from a single locality.

Vegetative reproduction seems to be the rule in moss populations dwelling in the studied habitats. No sex organs or sporophytes have been observed in any of the recorded taxa.

\section{Descriptions}

Descriptions, with comments on closely related taxa, will be given for only the four new to Sudan records.

Philonotis dregeana (Müll. Hal.) A. Jaeger, 1875. (Figure 2)

Syns. Bartramia dregeana Müll. Hal.; Philonotis androgyna (Hampe) A. Jaeger; Bartramia androgyna Hampe; B. afrouncinata Müll. Hal.; Philonotis afrouncinata (Müll. Hal.) Par.; P. pernana (Müll. Hal.) Par.; P. afrocapillaris Dix. ex Sim.

Plants up to $6 \mathrm{~mm}$, erect, sometimes creeping; having aerial branches; up to $5 \mathrm{~mm}$ high. Stem with small central strand in cross section, thin-walled inner cortical cells, and one row of thick-walled outer cortical cells. Leaves imbricate above to appressed at base when dry, erect to erecto-patent when moist, ovate-lanceolate to triangular-lanceolate, up to $0.55 \mathrm{~mm}$ long; apex acuminate, margin plane to recurved, serrate, bi-ranked, costa excurrent, percurrent, rarely ending below apex; dorsal superficial cells prosate, lamina cells rectangular, (30) $35 \mu \mathrm{m} \times 5(10) \mu \mathrm{m}$ above, mostly smooth, sometimes mamillate in the upper side, thin to very thick walled, quadrate to rectangular, $25 \mu \mathrm{m} \times 12.5 \mu \mathrm{m}$ at base, thin walled, forming a \pm distinct group of basal cells.

Note: Doubly serrate leaf margins and \pm distinct group of basal cells distinguish this plant from Philonotis marchica which has a wide range of characters and may be confused with $P$. dregeana.

Philonotis fontana (Hedw.) var.? caespitosa (Jur.) Limpr., 1875. (Figure 3) Syn.: P. caespitosa Jur.

Plants up to $8 \mathrm{~mm}$ long, dense aerial branches arise from reddish creeping stem. Leaves patent to erecto-patent, straight to \pm falcate-secund at ends of stem when dry, ovate to ovate-lanceolate, not plicate; upper leaves short ovate; ca $0.3 \mathrm{~mm}$ long, $0.17 \mathrm{~mm}$ wide, concave, lower leaves lanceolate with a broad base; up to $0.7 \mathrm{~mm}$ long; apex acuminate to acute; margin bluntly toothed above, entire at base, bi- or uni-ranked, plane to recurved; costa percurrent to short excurrent, sometimes ending below apex in the lower leaves, dorsal superficial cells prosate above; lamina cells long hexagonal, pentagonal, rectangular, $c a 35 \mu \mathrm{m} \times 15 \mu \mathrm{m}$ above, cell wall thick to thin, \pm quadrate, $c a 15 \mu \mathrm{m} \times 15 \mu \mathrm{m}$ at base, cells mamillate at upper or lower ends especially in old leaves.

Note: According to Flowers (1973), the range of characters of this variety is about the same as the species. He noticed that many small specimens of the species proper have leaves without plication at the base or with margins fairly plane above and singly serrate. Thus he had referred all forms of the species (fontana) to the species proper with no designation of variety or form. Since the specimens collected here from Khartoum are apparently small, we could not refer them with certainty to the variety caespitosa. 

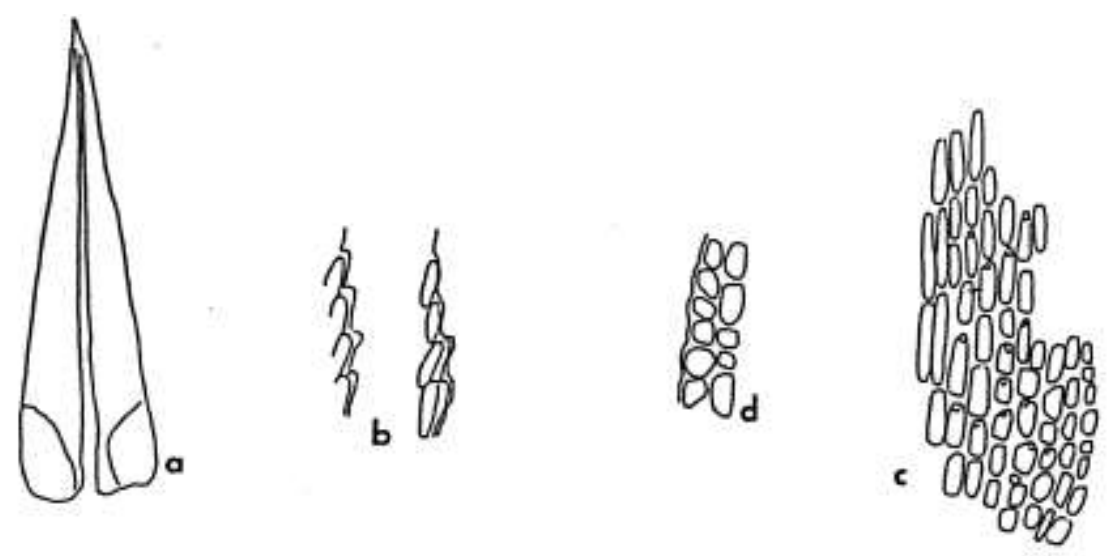

Fig. 2. Philonotis dregeana: a. leaf x 110; b. marginal cells at upper part of leaf x 246; c. cells at lower part of leaf x 192; d. marginal cells at base x 308 .

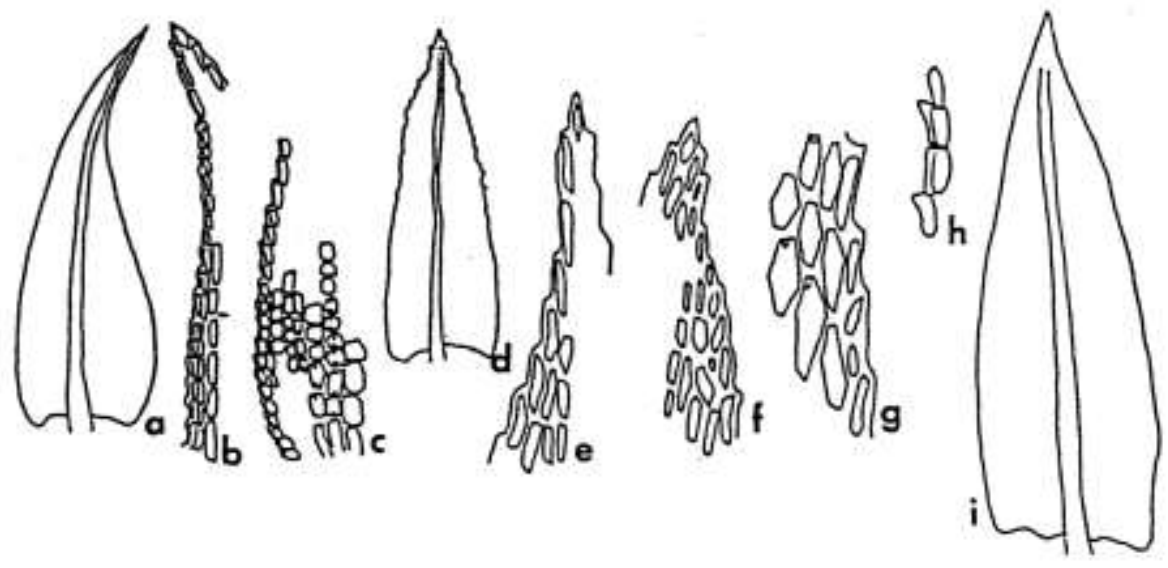

Fig. 3. Philonotis fontana var. ? caespitosa: a,d. leaves x 123, x 146; b,e, f. leaf apices x 120, x 292 , x 246 ; c. leaf base x 120 ; g. cells at middle part of the leaf 
x 292; h. marginal cells x 256; i. lower leaf x 88 .

Philonotis hastata (Duby) Wijk \& Margad, 1959 (Figure 4)

Syns.: P. imbricatula Mitt., P. laxissima (Müll. Hall.) Mitt., P. obtusata Müll. Hall. ex Ren.\& Card., P. zuluensis Broth.\& Bryhn.

Plants up to $3.5 \mathrm{~mm}$ high, green above, brownish at base. Stem mostly branched, rounded in cross section, central strand small. Leaves imbricate when dry, erecto-patent below and imbricate above when moist; heteromallous, ovate with acute, subacute or rarely rounded apecies above to lanceolate from ovate base below, with \pm acuminate apex in older parts or older plants; up to $0.5 \mathrm{~mm}$ long; margin plane or \pm recurved especially at base, crenulate by projecting cell ends, bluntly crenulate, marginal cells lax with adjacent ones; costa weak, sometimes strong, ending below apex, rarely percurrent, dorsal superficial cells rectangular, usually prosate, \pm homo-genous in cross section; lamina cells \pm homogenous along the leaf, rectangular, hexagonal, oblong-hexagonal, pentagonal, rarely quadrate, $20-30 \mu \mathrm{m} \times 10(20) \mu \mathrm{m}$ above to $20-35 \mu \mathrm{m} \times 15 \mu \mathrm{m}$ at base, cells smooth, cell wall thin to thick, firm to lax especially at leaf margin. Ramuli present in all collected samples. Rhizoidal gemmae rarely present.

Note: Since Philonotis hastata is highly polymorphic it may be confused with other taxa recorded in the region, e.g. P. dregeana where lax marginal cells of $P$. hastata may be confused with bi-ranked marginal cells of $P$. dregeana but this latter species has regularly narrow rectangular lamina cells and narrower lanceolate leaves. Leaves of old $P$. hastata plants may be confused with $P$. fontana var. caespitosa, but lamina cells of the latter have always mamillae in upper and/or lower ends especially in old leaves.

Gymnostomum aeruginosum Sm. var. cochlearifolium Karczmarz, 1981. (Figure 5).

Plants ca $6.5 \mathrm{~mm}$ high, yellowish green. Stem erect, rounded in cross section, cortical cells large and rounded, central strand small. Leaves lingulate to ligulate $c a 0.75 \mathrm{~mm}$ long, erect when dry, erecto-patent when moist, \pm concave; apex obtuse to rounded, apical cells papillose; margin plane, papillose-crenulate above, entire at base; costa ending below apex, ca $50 \mu \mathrm{m}$ wide at base, semicircular in cross section, with two median guide cells, dorsal and ventral stereid bands, ventral superficial distinct; lamina cells \pm quadrate to hexagonal above, $c a 6.6 \mu \mathrm{m} \times 6.6 \mu \mathrm{m}$, densely papillose, rectangular to quadrate at base, up to $20 \mu \mathrm{m} \times 8.25 \mu \mathrm{m}, \pm$ mamillate, cell wall thick at base.

Note: This taxon is strongly related to that recorded by Karczmarz (1981) except for the strong concavity of leaves in Nepal. It differs from Gymnostomum aeruginosum by its very obtuse leaf apex and from G. calcareum by shorter basal leaf cells; ca $20 \mu \mathrm{m}$ x $8 \mu \mathrm{m}$ vs. $30 \mu \mathrm{m}$ x $10 \mu \mathrm{m}$ in $G$.

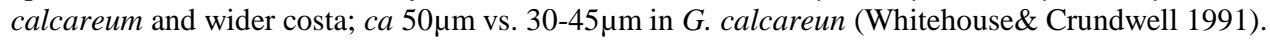

\section{Floristic Comparisons and Discussion}

The dominance of Philonotis in the four studied localities of Khartoum Province is not astonishing since most of the earlier records of species ( $\mathrm{ca} 77 \%$ ) of this genus were also from Af2*; the region to which the Sudan belongs: Wijk et al. (1959-69); Crosby (1977,79); Crosby\& Bauer (1981,83); Crosby et al. (1992), Crosby\& Magill $(1994,97)$. 
* as defined in Wijk et al. 1959- 69.
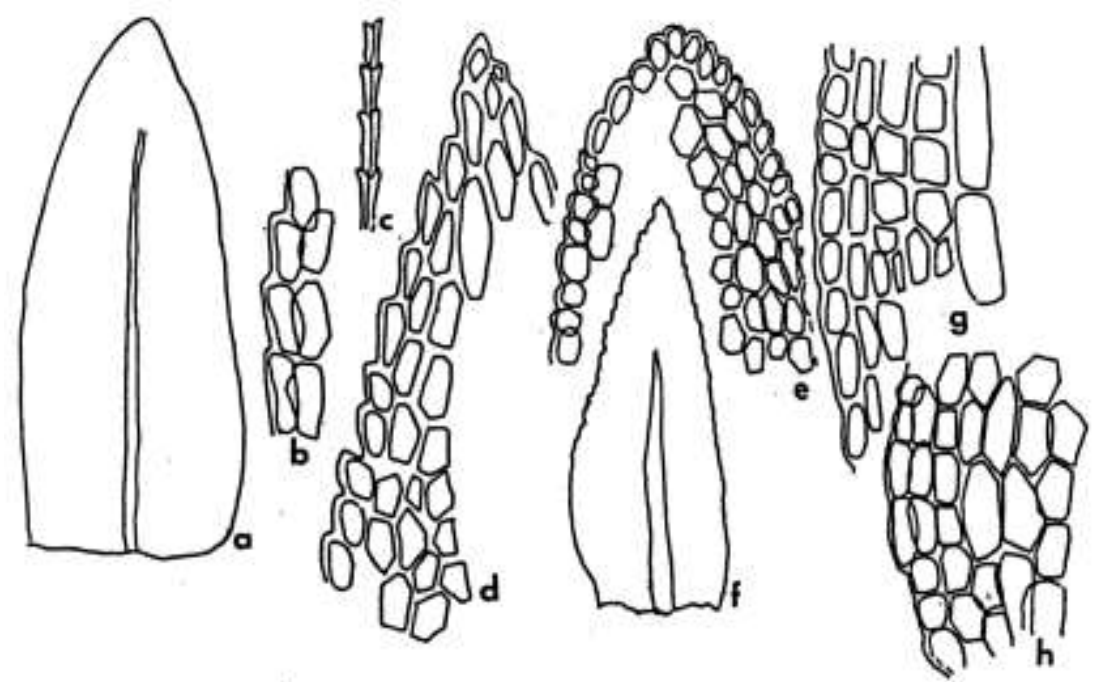

Fig. 4. Philonotis hastata: a,f. leaves $\mathrm{x} 154$, x 92; b. marginal cells $\mathrm{x} 230$; c. costal surface view $\mathrm{x}$ 92; d,e. leaf apices x 185, x 144; g,h. basal leaf cells x 185, x 185 .
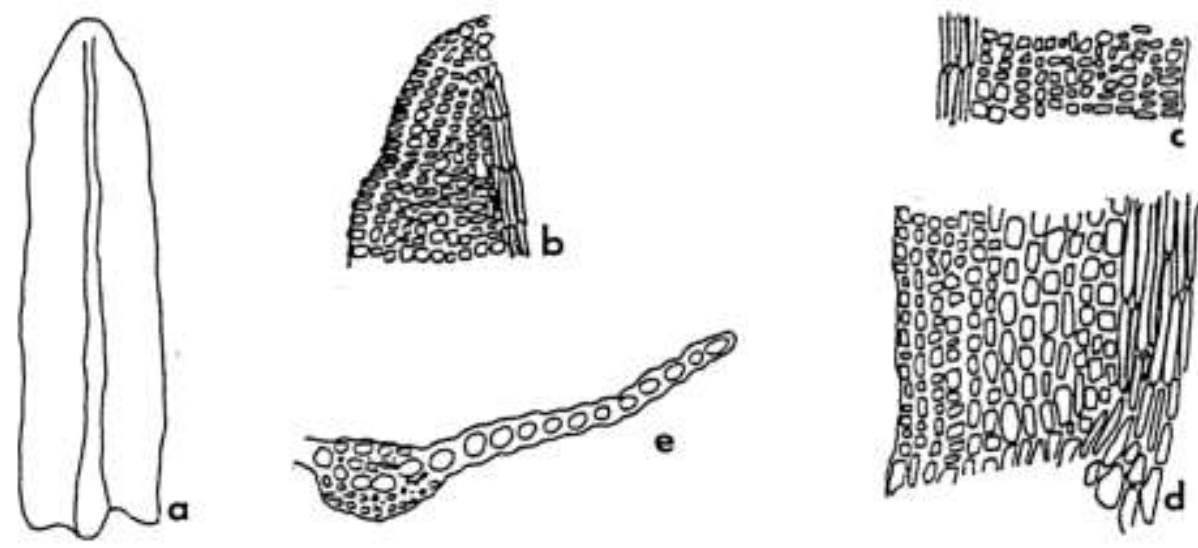

Fig. 5. Gymnostomum aeruginosum var. cochlearifolium: a. leaf x 67; b. leaf apex x 200; c. median cells of leaf x 185; d. cells of leaf base x 267; e. cross section of leaf x 500 . 
The commonness of Philonotis hastata in most localities of the present study agrees with its widespread occurrence in Tropical Africa (Egunyomi, 1981), as being the most common species of the genus in Egypt (El-Saadawi et al., 1986a,b; 1987a,b), its occurrence in Chad (Frahm, 1978) and finally as a widely spread moss found in Tropical Africa, Southern Asia, Australia and South America (cf. Frahm, 1976).

It is worthy to mention that, in the present study area, the most favourable microhabitat for the growth of Philonotis (and the other mosses in general) are the outer surfaces of the pottery water pots "Zeers" followed by moist soil. In Egypt, the most favourable micro-habitat for Philonotis species are the moist red-bricks followed by moist soil, then the outer surface of "Zeers". It is worthy to mention that, red bricks and "Zeers" are made from the same material (burnt mud of the Nile).

The specimens here referred to Philonotis fontana may in fact belong to the variety caespitosa. All earlier known records of the variety were from *Eur, *As1,5 and *Am1 (Wijk et al. 1959-69; Crosby 1977, 1979 and Crosby\& Bauer 1981, 1983). If our specimens belong to the variety caespitosa, this will represent a new record, not only to Sudan but also to to *Af2. Gymnostomum aeruginosum var. cochlearifolium is also a new record to Af2. It is already known from *As3 (Karczmarz, 1981; Zander, 1993).

The present work raised the number of mosses known from Khartoum Province from a total of 8 to 14 entities, or from 6 to 11 fully identified taxa. For the Sudan, the total number of fully identified mosses is increased from 23 to 31 entities.

Floristic comparisons show that each of the three areas viz. Khartoum Province, Gebel Marra and Gebel Elba has its distinct floral elements to the extent that only two (Tortuls bogosica and Philonotis marchica) out of the 31 fully identified entities occur in two areas each. This distinction may be ascribed to climatic and habitat conditions (cf. Kassas \& Imam, 1957; Kassas, 1960; Obeid \& Mahmoud, 1971 and Bebawi \& Neugebohrn, 1991).

\section{Acknowledgement}

We wish to thank Dr. Mostafa Al-Shimi (Bot. Depart., Fac. of Sc., Suez Canal Univ.), for kindly supplying us with requested papers.

\section{References}

Bebawi, F.F.\& Neugebohrn, L. 1991. A review of plants of Northern Sudan . Deutsche Gefellschaft für Technische Zusammenarbeit (GTZ) GmbH Eschborn. 1- 294.

Crosby, M.R. 1977. Index Muscorum supplementum: 1974-1975. Taxon 26: 285- 307.

Crosby, M.R. 1979. Index Muscorum supplementum: 1976 - 1977. Ibid., 28 (1,2,3): 237 264.

Crosby, M.R.\& Bauer C.R. 1981. Index Muscorum supplementum : 1978 - 1979. Ibid., 30: 667 - 693.

Crosby, M.R.\& Bauer C.R.1983. Index Muscorum supplementum :1980 - 1981. Ibid., 32 (4): 670-691.

"* as defined in Wijk et al. 1959- 69. 
Crosby, M.R., Magill R.E.\& Bauer C.R. 1992. Index of Mosses 1963- 1989. Monographs in systematic Botany from the Missouri Botanical Garden 42:1-646.

Crosby, M.R.\& Magill R.E. 1994. Index of Mosses 1990- 1992. Ibid.,50: 1- 87.

Crosby, M.R.\& Magill R.E. 1997. Index of Mosses 1993- 1995. Ibid.,62: 1-106.

Egunyomi, A. 1981. The effectiveness of asexual reproduction in distribution of Philonotis. Hattori. Bot. Lab. 159-164.

El-Saadawi, W., Abou El-Kheir W.S.\& Darwish M.H. 1986a. Notes on Egyptian mosses with one new record. Lindbergia 12: 129-131.

El-Saadawi, W., Badawi A.\& El-Awadi H.1987a. The moss flora of Egypt 3. The Cairo Region. Ain Shams Science Bulletin 26 B: 295-320.

El-Saadawi, W., Badawi A.\& Refai M.S. 1986b. Mosses of the Nile Delta. Lindbergia 12: 106-110.

El-Saadawi, W., Badawi A.\& Shabbara H. 1987b.The moss flora of Egypt. IV. El-Fayum Province. Ain Shams Sci. Bull. 26B: 321-356.

Flowers, 1973 Mosses Utah and West. Edited by Arthur Holmgren Brigham Young Univ. Press.

Frahm, J.P. 1976. Additions to the Moss flora of the Ivory-coast (Africa). Cryptogam. Bryol. Lichenol. 5(3): 281- 284.

Frahm, J.P. 1978. Zur Moosflora der Sahara, Nova Hedwigia 30: 527- 548.

Harrison M.N.\& Jackson J.K. 1958. Ecological Classification of the vegetation of the Sudan. Forests Bulletin 2: 1-45, Forests Department, Khartoum.

Imam, M.\& Ghabbour S.I. 1972. A contribution to the moss flora of Egypt. Bot. Notiser 125 (4): $518-522$.

Karczmarz, K. 1981. Bryophytes from Nepal. Lindbergia 7: 126- 130.

Kassas, M. 1960. Certain aspects of landform effects on plant water resources. Bull. Soc. Geog. d'Egypt, 28: 45- 52.

Kassas, M.\& Imam, M. 1957. Climate and microclimate in the Cairo Desert. Ibid 30: 2552.

Obeid, M. \& Mahmoud, A. 1971. Ecological Studies in the vegetation of the Sudan. II. The Ecological Relationships of the vegetation of Khartoum Province. Vegetatio 23 (3-4) : 177-198.

Pette, A. 1966. Bryophytes of the Sudan. 1. Khartoum Province. Transactions British Bryological Society 5:316-331.

Townsend, C.C. 1984. A small collection of Mosses from Jebel-Marra, Sudan. Lindbergia 10 (3) : 175-180.

Whitehouse, H.L.K. \& Crundwell, A.C. 1991. Gymnostomum calcareum Ness \& Hornsch. And allied plants in Europe, North Africa and Middle East. J. Bryol. 16:561-

Wickens, G.E. 1976. The flora of Jebel Marra (Sudan Republic) and in geographical affinities. Kew. Bull. Additional Ser, 5 : 1-368.

Wijk, R., Margadant, W.D. \& Florschiitz, P.A. 1959-69. Index Muscorum, 1-5, Regnum vegetable 17, 26, 33, 48 \& 65.

Zander, R.H. 1993. Genera of the Pottiaceae : Mosses of Harsh Environments. Bulletin of the Buffalo Society of Natural Sciences. 32. Buffalo, N.Y. 
New records to the Bryoflora Sudan

Received 17 January 1999. Revision accepted 3 April 1999

$-26-$ 